\title{
Fruit and seed floras from exceptionally preserved biotas in the European Paleogene
}

\author{
Margaret E. Collinson, Steven R. Manchester, Volker Wilde \& Peta Hayes
}

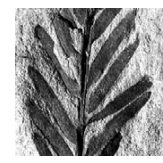

\begin{abstract}
Fossil fruit and seed assemblages from two exceptionally preserved biotas provide considerable information about systematics, diversity, dispersal biology and plant animal interactions in the European Paleogene. The first is from the Middle Eocene Messel oil shale in the Messel Pit near Darmstadt, Germany and occurs in association with exceptionally preserved flowers, insects and vertebrates. The second is from the latest Eocene Insect Limestone (Bembridge Marls Member, Solent Group) from the northern coast of the Isle of Wight, UK and occurs in association with exceptionally preserved insects. These two assemblages of compressed fruits and seeds both preserve delicate structures including plumes, wings and a fruit with a long awn. The Messel site also has rare, completely preserved fruiting heads and other specimens with organic connections, preservation of soft tissues, and seeds found within animal gut contents. The Messel flora is especially important for understanding Middle Eocene dispersal biology, biogeography and floristic diversity. - Key words: Messel oil shale, Eocene, biotic dispersal, wind dispersal, Insect Limestone, Bembridge Marls Member, plant fossil.
\end{abstract}

Collinson, M.E., MAnChester, S.R., Wilde, V. \& HAYes, P. 2010. Fruit and seed floras from exceptionally preserved biotas in the European Paleogene. Bulletin of Geosciences 85(1), 155-162 (1 figure, 1 table). Czech Geological Survey, Prague. ISSN 1214-1119. Manuscript received July 22, 2009; accepted in revised form October 5, 2009; published online January 12, 2010; issued xxxx xx, 2010.

Margaret E. Collinson (corresponding author), Department of Earth Sciences, Royal Holloway University of London, Egham, Surrey, TW20 0EX, UK, Department of Palaeontology, The Natural History Museum, Cromwell Road, London, SW7 5BD, UK; M.Collinson@es.rhul.ac.uk. For the other authors' addresses see the Appendix.

Exceptionally preserved biotas (Fossillagerstätten) are well known for providing information on ancient life that would not normally be available from more 'typical' preservation states (Selden \& Nudds 2004, Nudds \& Selden 2008). It is relatively unusual for both animal and plant remains to be preserved with high fidelity in the same Paleogene strata. Collinson (1988) drew attention to the special significance of the fruit and seed flora that is part of the Lagerstätte from the Eocene oil shale of Messel, Germany. In the 20 years since that publication much new material has been collected and Messel is now a World Heritage Site (Messel Pit Fossil Site). Therefore it is timely to update the status of research on this flora and place it in context with other European Paleogene exceptionally preserved biotas. To this end we are preparing a monograph on the Messel flora (Manchester et al.). For general overviews of the Messel site and its biota see the following: Schaal \& Ziegler (1992), Habersetzer \& Schaal (2004), Harms \& Schaal (2005), Schaal (2005), Gruber \& Micklich (2007).

Another Lagerstätte occurs in the latest Eocene Insect Limestone, from the Isle of Wight, UK, well known for its exceptionally preserved insects. The associated flora is one from a series of Paleogene fruit and seed floras from the
London and Hampshire Basins of southern England, that range from the latest Paleocene to earliest Oligocene. These assemblages have been reviewed and summarised in Collinson \& Cleal (2001) and they span three major intervals of global climate change, the Paleocene-Eocene thermal maximum, the Eocene climatic optimum and the EoceneOligocene greenhouse to icehouse transition. Various recent studies have addressed these climate changes using the UK succession (Collinson \& Hooker 2003; Grimes et al. 2005; Hooker et al. 2004, 2007, 2009a, b; Collinson et al. 2009; Sheldon et al. 2009). The Insect Limestone is the only flora within this series of assemblages that is associated with abundant exceptionally preserved insect remains.

Readers wishing to obtain a broader overview on European Paleogene floras should consult Mai (1995), Collinson \& Hooker (2003), Utescher \& Mosbrugger (2007), Kvaček (2010), each of which provides different perspectives on vegetation history and links to climate change as well as comprehensive reference lists.

Plants from these exceptionally preserved biotas, together with other significant sites of Europe, form the basis for our understanding of Paleogene systematics, paleoecology and biogeography. Other floras, although 
not with the status of Lagerstätten, nevertheless document the Paleogene history of plants and vegetation. In this paper we concentrate on the fruit and seed floras found as compressions and do not discuss the permineralized remains. Other floras include those from additional sites in the UK (Collinson \& Cleal 2001a-c) and Germany (Mai 1995; Mai \& Walther 1978, 1985, 2000).

The Weisselster Basin floras of Germany (Mai \& Walther 1978, 1985, 2000) include three late Middle Eocene localities (Floristic complex Scheiplitz), 52 late Eocene localities (Floristic complex Zeitz) and many Oligocene localities (Floristic complex Haselbach). These floristic complexes provide a combination of both leaf and fruit and seed floras although the early Paleogene is not represented there. However, faunal remains are few or lacking, so we do not consider these floras to belong to exceptionally preserved biotas.

The Middle Eocene Geiseltal flora of Germany comprises material which was derived from a number of individual sites in the Geiseltal browncoal mining district that span the complete Middle Eocene [reviews with reference lists in Wilde (1995) and Mai \& Walther (2000)] and is part of an historically well known exceptionally preserved biota (Voigt 1988). However, cessation of mining in these areas, with reclaiming and subsequent flooding of sites, has made it difficult, now impossible, to recollect these biotas (Wilde \& Hellmund 2006).

The fruit and seed flora from the Messel oil shale represents vegetation from a greenhouse world, postdating the Early Eocene climatic optimum but predating major Eocene cooling. In contrast, the flora from the Insect Limestone dates to the very latest Eocene after significant cooling had taken place. The aim of this paper is to review the exceptional nature of the fruit and seed flora from the Messel oil shale and consider its significance with particular focus on the range of dispersal biology existing in this greenhouse vegetation. Where possible a comparison will be made with the fruit and seed flora from the Insect Limestone.

\section{Context of the exceptionally preserved biotas}

The fruit and seed flora from the Messel oil shale. - The flora is preserved in organic-rich claystones (oil shale). The organic fraction is dominated by cell walls of the tiny ( $\mathrm{ca}$ $4 \mu \mathrm{m}$ ) freshwater alga Tetraedron (Goth 1990). The Messel oil shale (= Middle Messel Formation of Felder \& Harms 2004 as modified by Lenz et al. 2007) is dated to about 47 Ma (middle Middle Eocene; Mertz \& Renne 2005), and is well known for its exceptionally preserved flora and insect and vertebrate fauna (Schaal \& Ziegler 1992; Habersetzer \& Schaal 2004; Harms \& Schaal 2005; Schaal 2005; Gruber \& Micklich 2007; Wilde 2004; Manchester et al. 1994, 2007; Smith et al. 2009). Initial overviews of the fruit and seed flora were given in Collinson $(1982,1988)$; individual taxa have been published in detail since then (Manchester et al. 1994, 2007; Smith et al. 2008 in press; Wilde \& Manchester 2003) and a monographic treatment of the fruit and seed flora, recognizing more than 130 species, is currently in preparation (Manchester et al. in progress).

The Insect Limestone fruit and seed flora. - The Insect Limestone flora is preserved in a very fine-grained micrite within the basal part of the Bembridge Marls Member of the Bouldnor Formation, Solent Group. Hooker et al. (2007, 2009a) re-identified the Eocene-Oligocene transitional interval magnetochrons in Gale et al. (2006) and confirmed that at least the lowest 4.5 metres of the Bembridge Marls Member are latest Eocene in age belonging in subchron 1 of Chron C13r and not in Chron C13n. The biostratigraphy indicates that the position of Chron $\mathrm{C} 13 \mathrm{n}$ should lie higher in the sequence in the hiatus below the Nematura bed of the overlying Hamstead Member (Hooker et al. 2004, 2007, 2009a). Hence, the Insect Limestone is now considered to be latest Eocene in age.

The Insect Limestone contains an extremely diverse insect fauna exceptionally preserved in 3D (McCobb et al. 1998) which is currently being monographed as part of a major INTAS funded project led by Andrew Ross (National Museum of Scotland, Edinburgh) that will form a future issue of Special Papers in Palaeontology. The Insect Limestone (Bembridge) flora was initially monographed by Reid \& Chandler (1926), summarised and discussed by Chandler (1963) and Collinson et al. (1993) and recently reviewed and revised by Hayes \& Collinson (submitted).

\section{The special significance of the fruit and seed flora from the Messel oil shale}

\section{Exceptional preservation}

The following are examples of exceptional preservation of individual Messel fruits and seeds; it is the combination of all of these in one flora that makes Messel truly exceptional. 1) Persistence of delicate structures, such as 'plumes' and wings on seeds and fruits (Fig. 1A, B, D-F, H). 2) Complete fruiting heads or complete fruits. Examples include fruiting cycles of Cyclanthus (Cyclanthaceae) (Smith et al. 2008) and fruiting heads of Volkeria (Cyperaceae) which also have attached stamens (Smith et al. 2009) and a fruiting head of Magnoliaceae (Fig. 1M). 3) Fruits attached to axes or to leafy shoots providing evidence of organ connection e.g. Cedrelospermum (Wilde \& Manchester 2003) and several unpublished examples. 4) Clusters of fruits which may reflect the original grouping of fruits in life. An example is the grouping of eight Menispermaceae endocarps figured in Wilde (2005, p. 15) that implies comparable fruit grouping to that seen in the modern family. 
5) Preservation of fleshy or soft tissues where a typical fruit and seed flora would contain only the physically and chemically more resistant fruit stones or seed coats. Examples include the fleshy hypocarp of Anacardium (Anacardiaceae) (Manchester et al. 2007; Fig. 1R); fleshy fruits of the Lauraceae (Fig. 1C); a many-seeded fruit of possible musaceous affinity (Fig. 1N); several different genera of Vitaceae seeds, sometimes still contained within soft tissues of the fruit (e.g. Fig. 1O); and seeds of unknown affinity with well preserved arils (Fig. 1I). 6) Preservation of fruit endocarp or seed within a fruit pericarp cuticle such that presence of soft mesocarp or other soft fruit tissues can be reliably inferred. One very clear example is the endocarps of Menispermaceae surrounded by a pericarp cuticle Collinson (1982, plate 1, fig. 1). This same taxon preserves a distinctive fibrous flange in the plane of symmetry (Fig. 1L) not known in any other fossil menisperms.

\section{Dispersal biology and animal plant interaction}

Evidence of potential animal dispersal at Messel comes from the presence of fleshy or soft tissues on various fruits (see above). These include (Fig. 1C, O, R) the Vitaceae, Anacardium, Lauraceae and Menispermaceae, which are likely to have been mammal or bird dispersed, and the small arillate seeds (Fig. 1I) that are likely to have been insect-dispersed. In addition, isolated seeds are commonly recovered that may be inferred to have been from fleshy fruits based on their extant relatives [e.g., Vitaceae, Menispermaceae, Anacardiaceae such as Lannea (Fig. 1S)]. Vitis (Vitaceae) fruits containing seeds are known to have been eaten by mammals, namely the palaeothere Eurohippus, a sister taxon to the Equidea (true horses) (Franzen 2006, 2007; Koenigswald \& Schaarschmidt 1983). These palaeotheres may well have been dispersing the seeds as they are found intact in the gut rather than fragmented.

A different taxon of seeds occurs in the gut content of the rodent Masillamys from Messel. The same seeds are known as complete seeds in the oil shale (Collinson 1988) but unfortunately their taxonomic affinity still remains unknown. In this case the rodents were predating, rather than dispersing, the seeds as indicated by the fragmentation within the gut content.

Another example of seed predation is shown in Rutaspermum chandlerae (Rutaceae) seeds (Collinson \& Gregor 1988) that contain borings that are comparable to those made in modern flowering plant grains by weevils. They represent the earliest evidence of this interaction in the fossil record and are notable for their specificity being present in this single seed type at Messel and at other sites (Collinson 1999).

Spiny fruits (Fig. 1P) are very rare in the Messel flora. There is no obvious indication (such as barbs or curved tips) that the spines functioned for attachment to mammalian hair for dispersal (epizoochory) and other functions, such as protection, are hypothesized to be more likely. Modifications for epizoochory are extremely rare in the Paleogene (Collinson \& van Bergen 2004).

Large dry nuts are also extremely rare at Messel. There are two specimens of large, Carya-like fruits but no large nuts of the Betulaceae or Fagaceae. Such large nuts become more abundant in the late Eocene coincident with radiations of rodents and with the earliest direct evidence of seed predation by rodent gnawing, albeit on smaller seeds (Collinson \& Hooker 2000). The earliest examples of larder hoarding are Neogene (Gee et al. 2003). Therefore, there is no direct or indirect evidence of animal interaction with large dry fruits or seeds at Messel. However, large dry nuts are also absent from the latest Eocene Insect Limestone flora so there may also be taphonomic factors influencing their preservation in these exceptionally preserved biotas.

\section{Abiotic dispersal}

An example of a 'plumed' disseminule occurs at Messel, the Apocynospermum seed (Fig. 1A). This terminal coma of long simple uniseriate hairs probably functioned in wind dispersal as a guide parachute to aid orientation on landing (see Collinson \& van Bergen 2004). This seed type is widespread but rare in the Paleogene (Collinson \& van Bergen 2004, Appendix 18.1). In addition there is a hairy Populuslike seed at Messel. Examples like the Messel oil shale (and also Eckfeld - Wilde \& Frankenhäuser 1998 with similar preservation) and the Insect Limestone (see below) show that, even in these cases of exceptionally preserved biotas, 'plumed' propagules are both rare and of very low diversity. This suggests that the minimal diversity of Eocene 'plumes' (Collinson \& van Bergen 2004) is unlikely to be the result of absence due to preservational bias in fossil floras.

Collinson \& van Bergen (2004) reviewed the wide variety of Paleogene fruits and seeds with wings, noting that they were able to exploit a range of flight paths, trajectories and attitudes in flight. At Messel there are several members of Juglandaceae including trilobed bracts of Palaeocarya (Fig. 1D), four-winged propellers of Cruciptera (Fig. 1E), and the bilateral wings of Hooleya (Manchester et al. 1994), samaras of Cedrelospermum (Ulmaceae, Wilde \& Manchester 2003; Fig. 1H) and large bilateral wings of Ailanthus (Simaroubaceae, Fig. 1B). Other winged disseminules include Saportaspermum (Kvaček \& Wilde 2010; Fig. 1F), indet. Bignoniaceae, and two other indetermined genera. In the context of the overall Paleogene record, the diversity of winged fruits in the Messel flora is high, but not exceptional for this time interval. It is interesting that there are no encircling wings at Messel such as Cyclocarya or Paliurus so this supports the conclusion of Collinson (1988, p. 190) that only a small proportion of Messel fruit and seed fossils show modifications for wind dispersal. 
Dehiscent woody fruits are represented at Messel by follicles (Magnoliaceae, Fig. 1M), legume pods (Fig. 1Q), and capsules of euphorbiaceous affinity. Seeds with characteristic features of Hamamelidaceae (Fig. 1J) are associated with woody capsules for which explosive dehiscence may be inferred.

Although dust and microseeds are represented in Paleogene floras (Collinson \& van Bergen 2004), none have yet been documented in the Messel flora. Other than a genuine absence there may be two explanations for this. Firstly, seeds smaller than a $1 \mathrm{~mm}^{3}$ volume will be difficult to spot when studying bedding surfaces of blocks of oil shale in the field. The small seeds of Cyclanthus (ca 1.4-2.5 mm long, 0.6-0.9 mm wide, Smith et al. 2008) are amongst the smallest in the collections. Seeds like those of Cleyera (Fig. 1G) are more typical of the smallest size category of seeds in the collections from the Messel oil shale. Secondly, dust or microseeds may be contained within some of the fossil fruits for which internal details remain to be elucidated.

\section{Biogeography}

Considerations of the geographic areas where the Messel taxa occur today can contribute to our understanding of their subsequent phytogeographic history. The modern ranges are often greatly displaced from central Europe reflecting former pathways of dispersal and the effects of subsequent climatic change. A common pattern is with genera having their closest living representatives in eastern Asia, including $\mathrm{Ta}$ piscia (Fig. 1K), Toricellia, Ailanthus, Alangium and Palaeosinomenium. However, two recently published examples highlight Neotropical relationships. Both Anacardium (Manchester et al. 2007) and Cyclanthus (Smith et al. 2008) occur in the Middle Eocene fruit and seed flora from the oil shale of Messel in Germany and their living relatives are restricted to Central and South America.

Through comparison with other fossil floras of similar age, we gain insights into the geographic breadth spanned by various mesophytic and thermophilic taxa during the Eocene. Several taxa co-occur in the Eocene of the Messel oil shale, Germany; the Clarno nut beds, North America; and the London Clay, UK including Magnolia (Fig. 1M), (Magnoliaceae); Tapiscia (Fig. 1K), (Staphyleaceae); Meliosma (Sabiaceae); Nyssa (Nyssaceae); Palaeophytocrene (Icacinaceae) and Pentoperculum (Anacardiaceae). Toricellia (formerly misidentified as Lythraceae? by Collinson 1988) and winged Juglandaceae (e.g., Cruciptera and Palaeocarya) occur in Clarno as well as Messel. These distributions reflect former migration routes in the Northern Hemisphere (Tiffney 2000) and were probably attained via mid to high latitude land bridges that became available during the warm climate intervals of the Eocene.

\section{Diversity}

About 130 species in 34 families are currently recognised in the Messel fruit and seed flora (Manchester, Collinson \& Wilde in progress; Table 1). The flora includes occasional conifer remains (Doliostrobus scales) and numerous angiosperm families, plus ca 60 morphotypes of unknown or doubtful familial affinity. This diversity is similar to that of the Middle Eocene Clarno flora from western North America with 173 species based on fruits and seeds (Manchester 1994). Although there are well over 300 species from the Early Eocene London Clay flora this flora is not directly comparable as it spans a greater age range and has a much wider catchment (Collinson 1983) than the single lake ba$\sin$ in which the Messel flora accumulated. There are many elements in common with the London Clay flora and many of these are meso- to megathermal taxa which prove their survival in Europe after the Eocene climatic optimum. Furthermore there is a sustained high diversity and abundance of trees and lianas in nearest living relatives of these taxa indicating persistence of a structurally complex vegetation.

Figure 1. Fossil fruits and seeds from the Middle Eocene Messel oil shale that illustrate the range of dispersal biology represented in the Messel flora. Specimens are housed in the Senckenberg Forschungsinstitut und Naturmuseum, Frankfurt am Main (SM B) and the Hessiches Landesmuseum Darmstadt ( HLMD). Scale bars calibrated in mm. Specimens have been trimmed after collection and more fully exposed by removal of oil shale with a handheld sonication tool (Dentsply-Cavitron Model 700-II B). Specimens are immersed in water immediately after collection, during preparation and photography (the latter using strong side illumination) and finally stored in glycerol (with fungicide) to prevent desiccation. - A - Apocynaceae: Apocynospermum sp., plumed seed, SM B Me 7624. • B - Simaroubaceae: Ailanthus confucii Unger, fruit with bilateral wing, SM B Me 4006. - C - Lauraceae: pedunculate single-seeded fruit with epicarp cuticle and soft tissues, SM B Me 4114. $\bullet$ D - Juglandaceae: Palaeocarya winged fruit, SM B Me 8912. • E - Juglandaceae: Cruciptera simpsonii four winged fruit, SM B Me 17520. • F - Saportaspermum sp.: winged seed, SM B Me 21809. - G - Theaceae: Cleyera sp. small seed, SM B Me 20158. • H - Ulmaceae winged fruit: Cedrelospermum leptospermum (Ettingshausen, 1853) Manchester, 1987 emend. Wilde \& Manchester, 2003 SM B Me 7274. • I - unidentified arillate seed: inferred insect dispersal, SM B Me 2279. - J - Hamamelidaceous seed: inferred dispersal by explosive fruit dehiscence, SM B Me 4722. • K - Tapisciaceae: Tapiscia pusilla (Reid \& Chandler) Mai, SM B Me 12234. • L - Menispermeae fruit (unidentified, probable new genus): with a fibrous flange in the plane of symmetry SM B Me 20452. - M - Magnoliaceae: Magnolia multifolicle, HLMD Me 15680. • N - Musaceous fruit: soft tissues containing multiple seeds, SM B Me 20155. - O - Vitaceae fruit: soft tissues of fruit containing seed, SM B Me 7234. $\bullet$ P - unidentified spiny fruit: spines probably protective, not indicative of epizoochory SM B Me 2059. • Q - Leguminosae: woody dehiscent pod, SM B Me 20422. • R - Anacardiaceae: Anacardium germanicum Manchester et al., 2007. Fruit with fleshy hypocarp, SM B Me 7139. - S - Anacardiaceae: Lannea sp. endocarp, inferred to be from fleshy fruit, SM B Me 4882. 

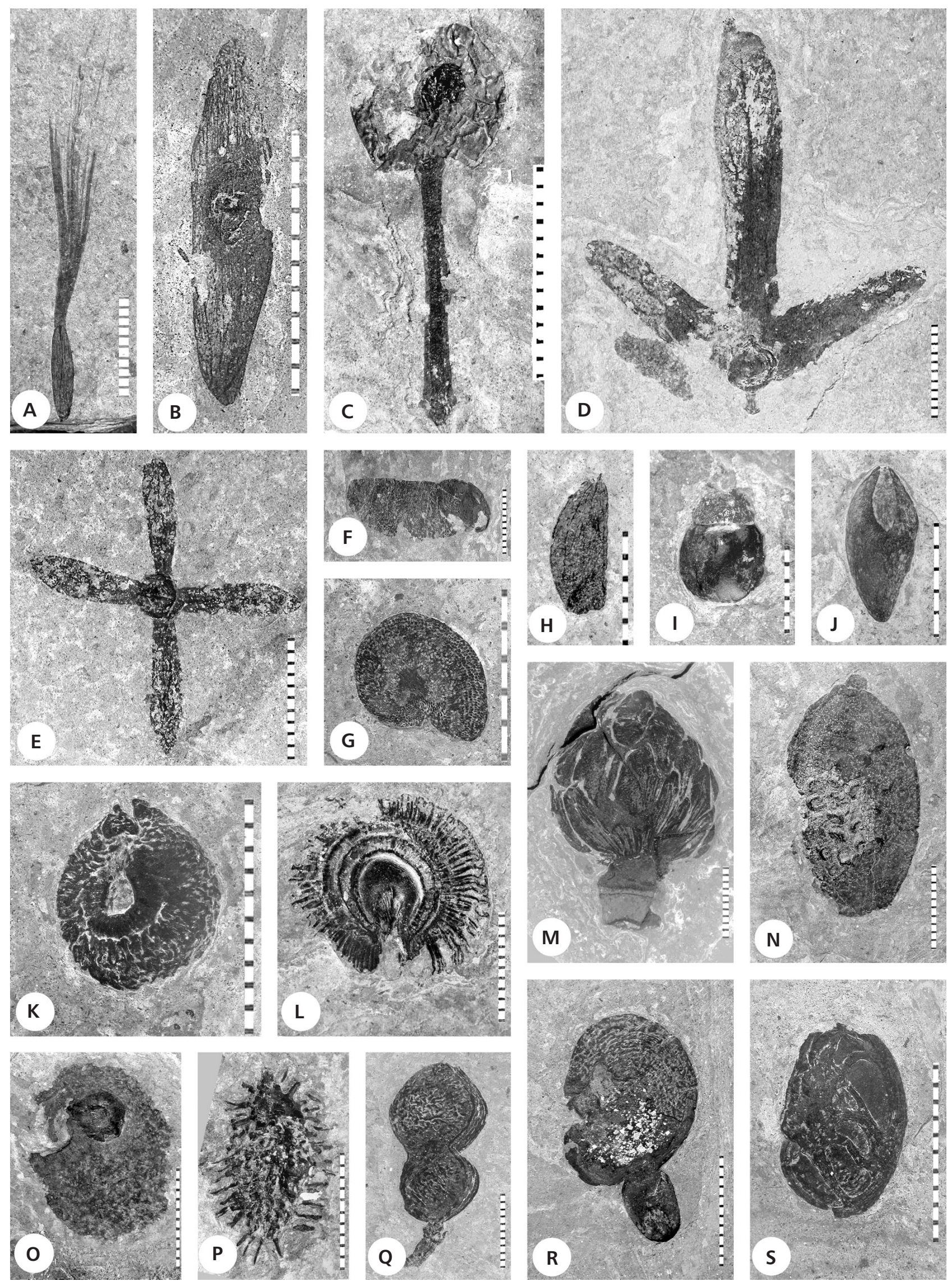
Table 1. List of the systematic affinities of fruits and seeds currently identified from the Messel oil shale. Generic names are stated when there is only a single genus identified within a family. Family concepts following Soltis et al. (2005).

$\begin{array}{ll}\text { Arecaceae } & \text { Magnoliaceae (Magnolia) } \\ \text { Alangiaceae (Alangium) } & \text { Mastixiaceae (3 morphotypes) } \\ \text { Altingiaceae } & \text { Menispermaceae (10 morphotypes) } \\ \text { Anacardiaceae (3 genera) } & \text { ?Musaceae } \\ \text { Apocynaceae } & \text { Myristicaceae } \\ \text { Bignoniaceae } & \text { ?Nymphaeales } \\ \text { Burseraceae (Canarium) } & \text { Nyssaceae (Nyssa) } \\ \text { Celtidaceae (Celtis) } & \text { Rutaceae (3 morphotypes) } \\ \text { Cyclanthaceae } & \text { Sabiaceae (Meliosma) } \\ \text { Cyperaceae } & \text { Salicaceae } \\ \text { Elaeocarpaceae (Sloanea) } & \text { Sapotaceae } \\ \text { Euphorbiaceae } & \text { Simaroubaceae (Ailanthus) } \\ \text { Hamamelidaceae } & \text { Tapisciaceae (Tapiscia) } \\ \text { Icacinaceae (3 genera) } & \text { Theaceae (Cleyera) } \\ \text { Juglandaceae (3 genera) } & \text { Toricelliaceae (Toricellia) } \\ \text { Lauraceae (ca } 3 \text { morphotypes) } & \text { Ulmaceae (Cedrelospermum) } \\ \text { Leguminosae (ca } 5 \text { morphotypes) } & \text { Vitaceae (5 morphotypes) }\end{array}$

\section{Comparison with the Insect Limestone flora}

Although the Insect Limestone flora is also part of an exceptionally preserved biota, its constituents are rather different to those from the Messel oil shale. Insects abound in the Insect Limestone as they do in the Messel oil shale but the Insect Limestone contains almost no vertebrate fossils, though the occurrence of one feather testifies to the fine scale structural detail preserved by the Limestone. Aquatic and wetland plants dominate the Insect Limestone fruit and seed flora whilst the Messel oil shale is dominated by trees and lianas, including, for example, numerous palms and diverse Menispermaceae, both of which are lacking in the Insect Limestone flora. Large fruiting heads, examples of organic connection and soft tissues are also lacking in the Insect Limestone fruit and seed flora. These differences can be partly explained by climate change between the Middle and latest Late Eocene and partly by different depositional settings and preservational processes.

Notable similarities between the Insect Limestone and Messel oil shale floras are the presence of (1) Apocynospermum, a 'plumed' seed, (2) various winged fruits and (3) a fruit with a long awn ( $c$ a 3 times fruit length). The winged fruits in the Insect Limestone include some taxa in common with those in the Messel oil shale (Hooleya and Palaeocarya) and others that differ such as Raskya (family uncertain - Manchester \& Hably 1997); Incertae Sedis (formerly 'Abelia') (Manchester \& Donoghue 1995); and Catalpa and Radermachera seeds (Bignoniaceae). Therefore the overall diversity of winged propagules is comparable to that in the Messel flora even though there are only two taxa in common.

Reid \& Chandler (1926) identified the awned fruit as Clematis and the Messel awned fruits seem to represent the same taxon, although further work is needed to confirm the systematic affinity. The Apocynospermum seed and awned fruit are not found elsewhere in the UK Paleogene (Collinson pers. obs.; Collinson \& Cleal 2001a-c). The widespread occurrences of the Apocynospermum seed (see above), the occurrences of the awned fruit in both the Messel oil shale and the Insect Limestone flora (separated in time and space), and the diversity of winged propagules in both floras, suggests that plumed, awned and winged fruits and seeds should be typical members of Eocene floras in Europe. They may be biased against and hence missing in fruit and seed floras studied from sieved residues.

\section{Conclusions}

Ongoing collecting research has added many new specimens and new determinations since Collinson (1988) reviewed the Messel fruit and seed flora. The exceptional preservation of this flora is especially important for understanding dispersal biology of this time interval, with preservation of delicate plumes and wings, fruiting heads and other examples of organ connection, soft tissues, and gut contents. The high diversity flora ( $c a 130$ species) now recognised provides information on biogeographic patterns and indicates the survival and persistence of mesothermal structurally complex vegetation in Europe after the Eocene climatic optimum. Comparison with a younger fruit and seed flora (from the latest Eocene Insect Limestone) reveals differences (e.g. absence of soft tissue preservation and fruiting heads) that reaffirm the special significance of the fruit and seed flora from the Messel oil shale. It also highlights the likelihood that survival of plumes, long awns and wings (present in both floras) is dependent on preservational conditions and study of fruit and seed fossils in situ rather than from sieved residues.

\section{Acknowledgements}

We would like to thank the late F. Schaarschmidt for his encouragement during our studies on the Messel flora and especially for the help and hospitality he gave to MEC and SRM during their many study visits to the Senckenberg Museum starting in the early 1980s. Throughout the years, K. Schmidt (Palaeobotany) and M. Müller (Messel Research) provided a lot of technical, curatorial and general help and support at the Senckenberg collections. Thanks are due to G. Gruber and N. Micklich for providing access to old collections and newly acquired material from the Hessisches Landesmuseum, Darmstadt. Partial support for work on Messel was provided by US National Science Foundation grants EAR 0174295 and BSR 0743474 to SRM and by a Royal Society 1983 University Research Fellowship (1983-1993) to MEC. For work on the Insect Limestone flora we acknowledge INTAS, the Natural History Museum, London, and the Royal Society for financial support for fieldwork and travel; and we thank 
M. Munt and the Dinosaur Isle museum, Isle of Wight, for access to collections; A. Yule for the material he has so keenly collected and generously donated to the Natural History Museum, London and A. Ross for overall support for this project. This paper contributes to INTAS Project No. 03-51-4367.

\section{Appendix}

Steven R. Manchester Paleobotany Section, Florida Museum of Natural History, Dickinson Hall 214, Museum Rd and Newell Drive, University of Florida, Gainesville, Florida 32611-7800, USA; Steven@flmnh.ufl.edu • Volker Wilde, Sektion Palaeobotanik, Senckenberg Forschungsinstitut und Naturmuseum, Senckenberganlage 25, 60325 Frankfurt am Main, Germany; Volker.Wilde@senckenberg.de - Peta Hayes, Department of Palaeontology, The Natural History Museum, Cromwell Road, London, SW7 5BD, UK; P.hayes@nhm.ac.uk

\section{References}

CHANDLER, M.E.J. 1963. Revision of the Oligocene floras of the Isle of Wight. Bulletin of the British Museum of Natural History (Geology) 6, 323-383.

COLlinson, M.E. 1982. A preliminary report on the Senckenberg-Museum collection of fruits and seeds from Messel bei Darmstadt. Courier Forschungsinstitut Senckenberg 56, 49-57.

COLLinson, M.E. 1983. Fossil Plants of the London Clay. 121 pp. Palaeontological Association Field Guides to Fossils Number 1, Palaeontological Association, London.

COLlinson, M.E. 1988. The special significance of the middle Eocene fruit and seed flora from Messel, West Germany. Courier Forschungsinstitut Senckenberg 107, 187-197.

COLLINSON, M.E. 1999. Evolution of angiosperm fruit and seed architecture and associated functional biology: status in the Late Cretaceous and Palaeogene, 331-337. In KURMANN, M.H. \& HEMSLEY, A.R. (eds) The Evolution of Plant Architecture. Royal Botanic Gardens, Kew.

COllinson, M.E. \& ClEAL, C.J. 2001a. Early and early middle Eocene (Ypresian-Lutetian) palaeobotany of Great Britain, 185-226. In Cleal, C.J., Thomas, B.A., BATTEN, D.J. \& Collinson, M.E. (eds) Geological Conservation Review Series, Mesozoic and Tertiary Palaeobotany of Great Britain. Joint Nature Conservation Committee, Peterborough.

Collinson, M.E. \& CleAL, C.J. 2001b. Late middle Eoceneearly Oligocene (Bartonian-Rupelian) and Miocene palaeobotany of Great Britain, 227-274. Ibid.

Collinson, M.E. \& CLEAL, C.J. 2001c. The palaeobotany of the Palaeocene and Palaeocene-Eocene transitional strata in Great Britain, 155-184. Ibid.

COllinson, M.E. \& GREGOR, H.J. 1988. Rutaceae from the Eocene of Messel, West Germany. Tertiary Research 9, 67-80.

COLlinson, M.E. \& HOOKER, J.J. 2000. Gnaw marks on Eocene seeds: evidence for early rodent behaviour. Palaeogeography, Palaeoclimatology, Palaeoecology 157, 127-149. DOI 10.1016/S0031-0182(99)00158-3

COLlinson, M.E. \& HoOKER, J.J. 2003. Paleogene vegetation of Eurasia: framework for mammalian faunas. Deinsea 10, 41-84.

COLLINSON, M.E., SINGER, R.L. \& HOOKER, J.J. 1993. Vegetation change in the latest Eocene of southern England, 81-87, pl.
XX-XXV. In Planderová, E., KonZÁlová, M., KVAČEK, Z., SitÁr, V., Snopková, P. \& Suballyová, D. (eds) Paleofloristic and paleoclimatic changes during Cretaceous and Tertiary. Geologický ústav Dionýza Štúra, Bratislava.

Collinson, M.E., StEART, D.C., HARRINGTON, G.J., HOOKER, J.J., SCOTT, A.C., ALLEN, L.O., GLASSPOOL, I.G. \& GIBBONS, S.J. 2009. Palynological evidence of vegetation dynamics in response to palaeoenvironmental change across the onset of the Paleocene-Eocene Thermal Maximum at Cobham, Southern England. Grana 48, 38-66. DOI 10.1080/00173130802707980

COLLINSON, M.E. \& VAN BERGEN, P.F. 2004. Evolution of angiosperm fruit and seed dispersal biology and ecophysiology: morphological, anatomical and chemical evidence from fossils, 344-377. In HEMSLEY, A.R. \& POOLE, I. (eds) The evolution of plant physiology. The Linnean Society of London.

FELDER, M. \& HARMS, F.-J. 2004. Lithologie und genetische Interpretation der vulkano-sedimentären Ablagerungen aus der Grube Messel anhand der Forschungsbohrung Messel 2001 und weiterer Bohrungen. Courier Forschungsinstitut Senckenberg 252, 151-203.

FRANZEN, J.L. 2006. Eurohippus n. g., a new genus of horses from the Middle to Late Eocene of Europe. Senckenbergiana lethaea $86,97-102$.

FrANZEN, J.L. 2007. Eozäne Equoidea (Mammalia, Perissodactyla) aus der Grube Messel bei Darmstadt (Deutschland). Mémoires suisses de Paléontologie 127, 1-243.

Gale, A.S., Huggett, J.M., PÄLIKe, H., LAURie, E., Hailwood, E.A. \& HARDENBOL, J. 2006. Correlation of Eocene-Oligocene marine and continental records: orbital cyclicity, magnetostratigraphy and sequence stratigraphy of the Solent Group, Isle of Wight, UK. Journal of the Geological Society, London 163, 401-415. DOI 10.1144/0016-764903-175

Gee, C.T., SAnder, P.M. \& Petzelberger, B.E.M. 2003. A Miocene rodent nut cache in coastal dunes of the Lower Rhine embayment, Germany. Palaeontology 46, 1133-1149. DOI 10.1046/j.0031-0239.2003.00337.x

GoTH, K. 1990. Der Messeler Ölschiefer, ein Algenlaminit. Courier Forschungsinstitut Senckenberg 131, 1-141.

Grimes, S.T., HOOKER, J.J., COLLINSON, M.E. \& MATTEY, D.P. 2005. Summer temperatures of late Eocene to early Oligocene freshwaters. Geology 33, 189-192. DOI 10.1130/G21019.1

GRUBER, G. \& MiCKLICH, N. (eds) 2007. Messel, treasures of the Eocene. 159 pp. The book to the exhibition Messel on Tour of the Hessisches Landesmuseum Darmstadt. Hessisches Landesmuseum Darmstadt, Darmstadt.

HABERSETZER, J. \& SCHAAL, S. (eds) 2004. Current geological and palaeontological research in the Messel Formation. Courier Forschungsinstitut Senckenberg 252, 1-245.

HARMS, F.-J. \& SCHAAL, S. (eds) 2005. Current geological and palaeontological research in the Messel Formation. Courier Forschungsinstitut Senckenberg 255, 1-236.

HAYes, P. \& COLlinson, M.E. submitted. Flora of the latest Eocene Insect Limestone. Special Papers in Palaeontology.

HoOKER, J.J., COLlinson, M.E. \& Sille, N.P. 2004. EoceneOligocene mammalian faunal turnover in the Hampshire Basin, UK: calibration to the global time scale and the major cooling event. Journal of the Geological Society of London 161, 161-172. DOI 10.1144/0016-764903-091

HoOKer, J., Collinson, M., GRIMES, S., Sille, N. \& MATtey, D. 2007. Discussion on the Eocene-Oligocene boundary in the UK. Journal of the Geological Society of London 164, 685-688. DOI 10.1144/0016-76492006-098

Hooker, J., Grimes, S., MAtTey, D.P., Collinson, M.E. \& 
SHELDON, N. 2009a. Refined correlation of the UK Late Eocene - Early Oligocene Solent Group and of its climate history. Geological Society of America Special Paper 452, 179-195.

Hooker, J.J., Collinson, M.E., LAwson, A.G., Tracey, S. \& SKIPPER, J.A. 2009b. The Woolwich Formation of Croydon, S. London, UK: a PETM fauna and flora rediscovered. GSN Science Miscellaneous Series 18.

KOENIGSWALD, W. VON \& SCHAARSCHMIDT, F. 1983. Ein Urpferd aus Messel das Weinbeeren frass. Natur und Museum 113, 79-84.

KVAČEK, Z. 2010. Forest flora and vegetation of the European early Palaeogene - a review. Bulletin of Geosciences 85(1), 3-16. DOI 10.3140/bull.geosci.1146

KVAČEK, Z. \& WILDE, V. (2010). Foliage and seeds of malvalean plants from the Eocene of Europe. Bulletin of Geosciences 85(1), 103-122. DOI 10.3140/bull.geosci.1170

LENZ, O.K., WILDE, V. \& RIEGEL, W. 2007. Recolonization of a Middle Eocene volcanic site: quantitative palynology of the initial phase of the maar lake of Messel (Germany). Review of Palaeobotany and Palynology 145, 217-242. DOI 10.1016/j.revpalbo.2006.11.001

MAI, D.H. 1995. Tertiäre Vegetationsgeschichte Europas: Methoden und Ergebnisse. 691 pp. Gustav Fischer Verlag, Jena.

MAI, D.H. \& WALTHER, H. 1978. Die Floren der Haselbacher Serie im Weisselster-Becken (Bezirk Leipzig, DDR). Abhandlungen des Staatlichen Museums für Mineralogie und Geologie zu Dresden 28, 1-200.

MAI, D.H. \& WALTER, H. 1985. Die obereozänen Floren des Weisselsterbeckens und seiner Randgebiete. Abhandlungen des Staatlichen Museums für Mineralogie und Geologie zu Dresden 33, 1-260.

MAI, D.H. \& WALTHER, H. 2000. Die Fundstellen eozäner Floren des Weisselster-Beckens und seiner Randgebiete. Altenburger Naturwissenschaftliche Forschungen 13, 1-59.

MANCHESTER, S.R. 1994. Fruits and seeds of the Middle Eocene Nut Beds flora, Clarno Formation, Oregon. Palaeontographica Americana 58, 1-205.

Manchester, S.R. \& Donoghue, M.J. 1995. Winged fruits of Linnaeeae (Caprifoliaceae) in the Tertiary of Western North America: Diplodipelta gen. nov. International Journal of Plant Sciences 156, 709-722. DOI 10.1086/297293

MANCHESTER, S.R. \& HABLY, L. 1997. Revision of "Abelia" fruits from the Paleogene of Hungary, Czech Republic and England. Review of Palaeobotany and Palynology 96, 231-240. DOI 10.1016/S0034-6667(96)00055-3

Manchester, S.R., Collinson, M.E. \& GoTH, K. 1994. Fruits of the Juglandaceae from the Eocene of Messel, Germany, and implications for Early Tertiary phytogeographic exchange between Europe and western North America. International Journal of Plant Sciences 155, 388-394. DOI 10.1086/297176

MANCHESTER, S.R., Wilde, V. \& Collinson, M.E. 2007. Fossil cashew nuts from the Eocene of Europe: biogeographic links between Africa and South America. International Journal of Plant Sciences 168, 1199-1206. DOI 10.1086/520728

MCCOBB, L.M.E., DunCAN, I.J., JARZEMBOWSKI, E.A., STANKIEWICZ, B.A., WILlS, M.A. \& BRIGGS, D.E.G. 1998. Taphonomy of the insects from the Insect Bed (Bembridge Marls), late Eocene, Isle of Wight, England. Geological Magazine 135, 553-563. DOI 10.1017/S0016756898001204

MERTZ, D.F. \& RENNE, P.R. 2005. A numerical age for the Messel Fossil deposit (Unesco World Heritage Site) derived from ${ }^{40} \mathrm{Ar} /{ }^{39} \mathrm{Ar}$ dating on a basaltic rock fragment. Courier Forschungsinstitut Senckenberg 255, 67-76.

NudDS, J. \& SELDEN, P. 2008. Fossil ecosystems of North Amer- ica, a guide to the sites and their extraordinary biotas. $288 \mathrm{pp}$. Manson Publishing, London.

REID, E.M. \& CHANDLER, M.E.J. 1926. Catalogue of Cainozoic plants in the Department of Geology. Volume 1. The Bembridge Flora. 206 pp. British Museum (Natural History), London.

SCHAAL, S. ed. 2005. Messel Pit Fossil Site: Snapshots from the Eocene. Vernissage, UNESCO World Heritage Sites series 21(05), $13^{\text {th }}$ year, 151, 1-68.

SCHAAL, S. \& ZIEGLER, W. (eds) 1992. Messel: an insight into the history of life and of the Earth. 332 pp. Clarendon, Oxford.

SHEldon, N., MitChEll, R., COLlinson, M.E. \& HOOKER, J.J. 2009. Eocene-Oligocene transition palaeoclimatic and palaeoenvironmental record from the Isle of Wight, 249-259. In KOEBERL, C. \& MONTANARI, A. (eds) The Late Eocene EarthHothouse, Icehouse, and Impacts. Geological Society of America Special Paper 452.

SELDEN, P. \& NUDDS, J. 2004. Evolution of fossil ecosystems. 160 pp. Manson Publishing, London.

Smith, S.Y., Collinson, M.E. \& Rudall, P.J. 2008. Fossil Cyclanthus (Cyclanthaceae, Pandanales) from the Eocene of Germany. American Journal of Botany 95, 688-699. DOI 10.3732/ajb.2007390

Smith, S.Y., Collinson, M.E., Simpson, D.A., RudAll, P.J., MARONE, F. \& STAMPANONI, M. 2009. Elucidating the affinities and habitat of ancient, widespread Cyperaceae: Volkeria messelensis gen. et sp. nov., a fossil mapanioid sedge from the Eocene of Europe. American Journal of Botany 96, 1506-1518. DOI 10.3732/ajb.0800427

Soltis, D.E., SOlTIS, P.S., ENDRESS, P.K. \& CHASE, M.W. 2005. Phylogeny and evolution of angiosperms. 370 pp. Sinauer Press, Sunderland, Massachussets.

TIFFNEY, B.H. 2000. Geographic and climatic influences on the Cretaceous and Tertiary History of Euramerican floristic similarity. Acta Universitatis Carolinae, Geologica 44, 5-16.

UTESCHER, T. \& MOSBRUGGER, V. 2007. Eocene vegetation patterns reconstructed from plant diversity - a global perspective. Palaeogeography, Palaeoclimatology, Palaeoecology 247, 243-271. DOI 10.1016/j.palaeo.2006.10.022

VOIGT, E. 1988. Preservation of soft tissues in the Eocene lignite of the Geiseltal near Halle. Courier Forschungsinstitut Senckenberg 107, 325-343.

WILDE, V. 1995. Die Makroflora aus dem Mitteleozän des Geiseltalgebietes, kurze Übersicht und Vergleiche. Hallesches Jahrbuch für Geowissenschaften B 17, 121-138.

WILDE, V. 2004. Aktuelle Übersicht zur Flora aus dem mitteleozänen "Ölschiefer" der Grube Messel bei Darmstadt (Hessen, Deutschland). Courier Forschungstinstitut Senckenberg 252, 109-114.

WILDE, V. 2005. The Green Eocene - the diverse flora of a paratropical climate. Vernissage, UNESCO World Heritage Sites series 21(05), $13^{\text {th }}$ year, 151, 14-19.

WildE, V. \& FRANKENHÄUSER, H. 1998. The Middle Eocene plant taphocoenosis from Eckfeld (Eifel, Germany). Review of Palaeobotany and Palynology 101, 7-28. DOI 10.1016/S0034-6667(97)00067-5

WILDE, V. \& MANCHESTER, S.R. 2003 Cedrelospermum-fruits (Ulmaceae) and related leaves from the Middle Eocene of Messel (Hesse, Germany). Courier Forschungsinstitut Senckenberg 241, 147-153.

WildE, V. \& HellMuND, M. 2006. Neue Geländearbeiten im ehemaligen Braunkohlenrevier Geiseltal. Kooperation zwischen dem Forschungsinstitut Senckenberg in Frankfurt (Main) und dem Geiseltalmuseum am Institut für Geologische Wissenschaften in Halle (Saale). Natur und Museum 136, 162-173. 